\title{
Nidogen-1 C-Terminal Domain
}

National Cancer Institute

\section{Source}

National Cancer Institute. Nidogen-1 C-Terminal Domain. NCI Thesaurus. Code C19670.

The $20 \mathrm{kDa}$ C-terminal domain of the vascular basement protein, Nidogen-1. It may have anti-angiogenic properties. 